\title{
Body weight, eating practices and nutritional knowledge amongst university nursing students, Eastern Cape, South Africa
}

\author{
Authors: \\ Violet L. van den Berg \\ Alice P. Okeyo ${ }^{1}$ \\ Andre Dannhauser ${ }^{1}$ \\ Mariette $\mathrm{Nel}^{2}$

\section{Affillitions:} \\ ${ }^{1}$ Department of Nutrition and \\ Dietetics, University of the \\ Free State, South Africa \\ ${ }^{2}$ Department of Biostatistics, \\ University of the Free State, \\ South Africa \\ Correspondence to: \\ Violet van den Berg \\ Email: \\ vdbergvl@ufs.ac.za \\ Postal address: \\ PO Box 339, Bloemfontein \\ 9300, South Africa \\ Dates: \\ Received: 14 June 2011 \\ Accepted: 27 Apr. 2012 \\ Published: 21 Aug. 2012 \\ How to cite this article: \\ Van den Berg VL, Okeyo AP, \\ Dannhauser A, Nel M. Body \\ weight, eating practices \\ and nutritional knowledge \\ amongst university nursing \\ students, Eastern Cape, \\ South Africa. Afr J Prm Health \\ Care Fam Med. 2012;4(1), \\ Art. \#323, 9 pages. http:// \\ dx.doi.org/10.4102/phcfm. \\ v4i1.323
}

Background: Health care workers need to be equipped to deal with the increasing obesity and obesity-related morbidity occurring in developing countries.

Objectives: To assess weight status, eating practices and nutritional knowledge amongst nursing students at the University of Fort Hare, Eastern Cape.

Method: A cross-sectional descriptive survey was conducted on 161 undergraduate (51 male and 110 female) students of the Department of Nursing Sciences at the University of Fort Hare. Body mass index, waist and hip circumferences and waist hip ratio were determined. Nutritional knowledge and eating practices were investigated by structured intervieweradministered questionnaires.

Results: Statically, $49.7 \%$ were overweight or obese (58.2\% of the females; $31.4 \%$ of the males) and $65.2 \%$ had waist circumferences putting them at risk for non-communicable diseases. Most did not meet the recommendations for intakes from the vegetable group $(97.5 \%$ ate $<3$ servings per day), the fruit group ( $42.2 \%$ ate $<2$ servings per day), and the dairy group (92.6\% ate $<2$ servings per day); whilst $78.3 \%$ ate $\geq 4$ serving per day of sugar or sweets. Most consumed margarine, oil or fat (68.3\%), sugar (59.0\%) and bread (55.9\%) daily, but few reported daily intakes of vegetables $(12.4 \%)$, fruit $(23.6 \%)$, fruit juice $(21.2 \%)$ and milk $(15.6 \%)$. Fewer than $50 \%$ knew the recommended intakes for vegetables, fruit, dairy, starchy foods and meat or meat alternatives.

Conclusions: These nursing students had a high prevalence of overweight and obesity, poor eating habits and inadequate knowledge on key nutrition issues, which may impact negatively on their efficacy as future health ambassadors to the public.

Poids corporel, pratiques alimentaires et connaissances en matière de nutrition parmi les étudiants en sciences infirmières, Cap Oriental, Afrique du Sud

Contexte: Les travailleurs de la santé doivent être équipés pour faire face à l'augmentation de l'obésité et de la morbidité liée à l'obésité dans les pays en développement.

Objectifs: Évaluer le statut pondéral, les pratiques alimentaires et les connaissances en matière de nutrition des étudiants en sciences infirmières à l'Université de Fort Hare, Cap oriental.

Méthode: Une enquête transversale descriptive a été réalisée auprès de 161 étudiants de premier cycle (51 hommes et 110 femmes) du département des sciences infirmières à l'Université de Fort Hare. L'indice de masse corporelle, le tour de taille et de hanches et le rapport taille-hanche ont été déterminés. Les connaissances en matière de nutrition et les pratiques alimentaires ont été examinées à partir de questionnaires administrés par un enquêteur.

Résultats: Statistiquement, $49.7 \%$ étaient en surpoids ou obèses $(58.2 \%$ des femmes ; $31.4 \%$ des hommes) et $65.2 \%$ avaient un tour de taille augmentant le risque de souffrir de maladies non contagieuses. La plupart ne respectent pas les recommandations en termes d'apports alimentaires provenant du groupe alimentaire des légumes $(97.5 \%$ mangeaient moins de 3 portions par jour), du groupe alimentaire des fruits (42.2\% mangeaient moins de 2 portions par jour), et du groupe alimentaire des produits laitiers ( $92.6 \%$ mangeaient moins de 2 portions par jour); alors que $78.3 \%$ mangeaient 4 portions par jour de sucre ou de bonbons ou plus. La plupart consommaient de la margarine, de l'huile ou de la graisse $(68.3 \%)$, du sucre $(59.0 \%)$ et du pain (55.9\%) tous les jours, mais moins de 50\% mentionnaient un apport en légumes, fruits, produits laitiers, féculents et viande ou substituts de viande.

Conclusions: Ces étudiants en sciences infirmières présentaient un taux de prévalence de surpoids et d'obésité élevé, de mauvaises habitudes alimentaires et une méconnaissance des points nutritionnels clés.

\section{Introduction}

\section{Key focus}

South Africa, ${ }^{1}$ like other sub-Saharan African countries, ${ }^{2}$ has a double burden of disease. Undernutrition, with its outcomes of growth failure, stunting and micronutrient deficiencies, 
still occurs amongst children in developing communities; whilst overnutrition, leading to overweight and obesity, and non-communicable diseases (NCD), including hypertension, cardiovascular diseases and type 2 diabetes, is reaching epidemic proportions amongst adults in the same communities. ${ }^{1,2}$

\section{Background and Trends}

The South African Demographic and Health Survey (SADHS) 2003 found that $29.8 \%$ of South African adult men and 54.7\% of adult women (the four main races in the country combined) were either overweight or obese (had a body mass index [BMI] of $25-30 \mathrm{~kg} / \mathrm{m}^{2}$ or $>30 \mathrm{~kg} / \mathrm{m}^{2}$, respectively). ${ }^{3}$ The mean waist circumference for South African women in the SADHS was found to be $82.7 \mathrm{~cm}^{3}$, which is above the cut-off point for sub-Saharan females $(>80 \mathrm{~cm})^{4}$ that constitutes an increased risk for insulin resistance and the metabolic syndrome. A relatively high percentage of urban African women $(39 \%)^{3}$ also had a waist circumference of $>88 \mathrm{~cm}$, classified as a substantial risk for NCD. ${ }^{5}$ The health impact of these findings is emphasised by the South African National Burden of Disease Study which estimated that NCD, associated with a high BMI, accounted for $37 \%$ of all deaths in the country in $2000 .^{6}$

The etiology of obesity involves a complex interplay between genetics and environmental or lifestyle factors.,8 Eating practices associated with the global obesity epidemic include increased consumption of energy-dense, but nutrient-poor foods; 7,9 low consumption of dairy products ${ }^{10}$, fruits and vegetables ${ }^{9}$, skipping breakfast ${ }^{11}$; and insufficient physical activity. ${ }^{78}$ South Africa, like other developing countries, has been undergoing a transition from traditional high fibre, low fat diets, to typical Western diets that are high in fat, sodium and added sugars, and low in unrefined carbohydrate, dairy, fruits and vegetables; and from traditionally more active lifestyles, to more sedentary practices. ${ }^{1,12,13}$ These trends have been associated with the high prevalence of obesity amongst Black South African people, particularly women living in urban areas. ${ }^{3,12,13}$

Studies have shown that counselling interventions are effective in reducing risk and burden of disease in adults with hyperlipidemia and other risk factors for cardiovascular diseases. ${ }^{14}$ Since the public views primary care providers as valuable sources of nutritional guidance and lifestyle advice to prevent and treat NCD, health care professionals play a key role in this regard through patient education. . $^{16,16}$ However, studies identify significant barriers which prevent health care workers from offering dietary support; these include lack of time, of teaching materials, of nutritional knowledge and of confidence, on the part of the provider. ${ }^{18,19}$ Moreover, it seems from a recent systematic review, that health care professionals are more likely to discuss weight, diet and lifestyle issues with their patients and use strategies to prevent obesity in patients, if they themselves have a normal BMI. ${ }^{20}$ No published studies to date have addressed these issues amongst South African health care professionals.

\section{Objectives}

The training of health care professionals at colleges and universities offers the opportunity to develop sound knowledge, attitudes and practices regarding nutrition and weight. This study was undertaken to assess the body weight status, eating practices and nutritional knowledge of nursing students at the University of Fort Hare, and to investigate possible associations between these parameters.

\section{Research significance}

Nurses play a key role in addressing the emerging epidemic of overweight and obesity in South Africa on a primary level through patient education. Studies show however, that health care professionals are more likely to council patients on weight, diet and lifestyle issues if they themselves have a normal body mass index. No published studies to date have addressed these issues amongst South African health care professionals. This study was undertaken to assess the weight status, eating practices and nutritional knowledge of nursing students at the University of Fort Hare, Eastern Cape.

The baseline information gathered in this study may highlight knowledge, attitude or practice gaps which need to be addressed in order to empower nurses towards efficient diet and lifestyle counselling in South Africa.

\section{Ethical considerations}

All procedures of this study adhered to the Declaration of Helsinki on 'Ethical Principles for Medical Research Involving Human Subjects.' The study protocol was approved by the Ethical Committee of the Faculty of Health Sciences, University of the Free State (ETOVS NR 37/07). Permission to carry out the research was obtained from the Head of the Department of Nursing Sciences, University of Fort Hare. The study was conducted in 2007.

\section{Potential benefits and hazards}

Participation in the study involved no risk to the participants. In cases where health risks were identified in a subject during the study, participants received free dietetic advice and counselling. All information in the study was kept strictly confidential. During the reporting of the results the focus was strictly on group trends so that individual information remained confidential and anonymous within the study.

\section{Recruitment procedures}

All 200 nursing students enrolled at the institution, were contacted and informed of the study. No student was under any obligation to participate in the study, and those contacted were informed (orally and in writing) that their participation would be voluntary, and that they would not be penalized or lose benefits if they refused to participate, or wanted to withdraw from the study at any time. They were also informed that participants would not carry any costs and no participant would receive any compensation. 


\section{Informed consent}

All participants were pre-informed in writing about the purpose of the study and of the procedures to be used during the research. Students, who agreed to these terms signed letters of consent. Participants retained the written information sheets.

\section{Methods}

\section{Population and setting}

Two hundred full-time undergraduate students of 18 years and older, from the Department of Nursing Sciences, University of Fort Hare, Eastern Cape, South Africa were contacted - their names were obtained from the admissions list of the institution. A total of 161 students (51 male and 110 female) gave consent and were included in the study.

\section{Design}

A cross-sectional survey was conducted.

\section{Procedure}

The diagnosis of overweight or obesity and the risk for NCDs was based on the Body Mass Idex (BMI) and waist circumference, respectively, as recommended by both the International and Southern African Associations for the Study of Obesity (IASSO and SASSO). ${ }^{5}$ Waist-hip-ratios were also included as a measure of fat distribution..$^{21}$ All measurements were taken in light clothing and without shoes by the same trained researcher, using standardised techniques.,21 The average of three measurements was recorded.

Structured interviews with the participants were performed by the main researcher, who had been trained in nutrition at the University of the Free State. Interviews were conducted in a room at the Department of Nursing Sciences of the University at Fort Hare, and food photos and packaging were used to assist participants in recalling portion sizes and food choices. Eating practices were established by 24-hour recalls obtained during structured interviews with the participants. As a single 24-hour recall does not adequately represent usual food intake, three recalls (for Tuesdays, Thursdays and Saturdays) were recorded for each participant, and the average daily intakes were calculated. The United States Agricultural Department's Food Guide Pyramid 1992 (USAD-FGP) ${ }^{22}$ was used to evaluate the food intake, as this tool is familiar to South African students in health care, and quantifies the recommended daily number of portions to be consumed from each food group (as opposed to the South African Food-Based Dietary Guidelines [SAFBDG $]^{23}$ ). The Dietary Guidelines for Americans $2010^{24}$ was also used to interpret fat and sugar intakes (not included in the USDAFGP 1992). Average daily energy intakes were quantified from the data collected in the 24-hour recalls, using a standard exchange list based on the recommendations of the American Dietetic Association ${ }^{25}$, with portion sizes quantified from the South African Medical Research Council's (MRC) Food Composition Tables ${ }^{26}$ and the SA MRC Food Quantity
Tables. ${ }^{27}$ During the same interview, a food frequency questionnaire, which was adapted to reflect food choices of students and used to determine how often a particular food was consumed, was also administered.

Nutritional knowledge was recorded during structured interviews with the participants in their language of choice, using a questionnaire based on the recommendations of the USDA-FGP22, the Dietary Guidelines for Americans 2010 24 and the SAFBDG. ${ }^{23}$ Questions were asked regarding the food group to be eaten most frequently; the food group to be eaten the least; recommended number of daily servings from each food group; foods with high fat, sugar and fibre content; foods with low fat, sugar and fibre content; and foods high in vitamin $C$ and beta carotene. Students who had an overall score of more than $50 \%$ on the knowledge questionnaire were regarded as knowledgeable, whilst individuals who scored less than $50 \%$ were regarded as less knowledgeable. Students were also asked to identify their sources of nutritional information - be it their parents, their friends, the media or a school or institution of learning.

\section{Analysing}

A statistical data analysis was performed by the Department of Biostatistics of the Faculty of Health Science of the University of the Free State, and was generated by SAS® software (copyright, SAS Institute - SAS and all other SAS Institute Inc. products or service names are registered trademarks or trademarks of SAS Institute Inc., NC, USA.) Categorical data was presented as frequencies and percentages, and continuous data as medians and percentiles. To compare the underweight, normal weight and overweight or obese groups, $95 \%$ confidence interval [CI] for median differences or percentage differences were used.

\section{Results}

\section{Socio-demographic status of the nursing students}

The final sample of 161 students had a median age of 24.9 years (ranging from 18 to 42 years) and consisted of twothirds females (Table 1). There were $27.3 \%$, 26.1\%, 19.9\%, and $26.7 \%$ first, second, third and fourth year students, respectively. The majority $(96.3 \%)$ of the students were Black students; most of whom (87.6\%) were single; most (67.7\%) resided at the university hostels; and for most (42.2\%) students their permanent place of residence was in rural areas, followed by township places of residence (37.3\%). Those residing at the university hostels were responsible for procuring or preparing their own meals, as the campus does not offer a food service.

\section{Body weight status of the nursing students}

Based on the BMI-classification for adults, ${ }^{5,21} 46.7 \%$ of the participants were classified as either overweight (31.7\%) or obese $(15.0 \%)$ (Table 2). Overweight and obesity, respectively, were also more common amongst female 
students $(36.4 \%$ and $21.8 \%)$ than males $(21.6 \%$ and $9.8 \%)$. The waist circumference-values indicated that $65.2 \%$ of the participants were at risk for insulin resistance, the metabolic syndrome and thus for NCD, as defined by IASSO. ${ }^{5}$ Based on waist circumference and waist-hip-ratio ${ }^{21}, 38.5 \%$ and $37.3 \%$ of all the participants respectively, were at substantial risk for NCD as defined by IASSO. (Table 2)

\section{Eating practices of nursing students}

The majority of participants (59\%) ate three meals a day, $23.6 \%$ reported eating fewer than three meals per day, and all of them (161) indicated that lunch was the meal that they most frequently skipped. The usual daily food intake obtained from the average of three 24-hour recalls and compared to the recommendations of the USDA-FGP 22 and the Dietary Guidelines for Americans 2010. ${ }^{24}$ More than 9 out of 10 participants did not meet the minimum daily requirements for vegetables (97.5\%) and dairy or dairy products (92.6\%), and $42.2 \%$ did not consume the minimum recommended amount of fruit. Most participants (83.2\%) consumed adequate amounts of bread, cereal, rice and pasta daily, whilst $13.6 \%$ consumed more than the recommended 11 servings from this food group per day. Most participants (80.8\%) reported intakes above the minimum recommendations (two to three servings) for meat and meat substitutes. Most participants (78.3\%) also consumed 4 or more teaspoons $(40 \mathrm{~g}+)$ of added sugar and/or sweets per day; whilst half (50.3\%) the participants consumed more than $20 \mathrm{~g}$ of added fats and oils per day.

Most participants reported that they consumed margarine, oil or fat $(68.3 \%)$, sugar $(59.0 \%)$ and bread (55.9\%) daily, but few consumed vegetables $(12.4 \%)$, fruit $(23.6 \%)$, fruit juice $(21.2 \%)$, and dairy or dairy products $(15.6 \%)$ on a daily basis (Table 4). A large number $(77.0 \%)$ of the participants did not consume low fat or skim milk. Most participants (73.9\%) reported not using any alcohol and less than one per cent reported daily consumption of alcohol (Table 4). Self-reported alcohol intakes (Table 3) of most participants $\mathbf{( 9 8 . 8 \% )}$ were within the prudent guidelines of two or fewer drinks per day. ${ }^{28}$

\section{Nutritional knowledge of nursing students}

The majority of the participants (Table 5) did not know that starch should be eaten the most (68.3\%), but did know that fat or oil and sugar or sweets should be eaten the least (75.2\%). The majority of the participants also did not know the daily recommended number of servings that should be consumed from the bread, cereal, rice and pasta group (85.7\%), the vegetables group (54.7\%), the milk or yoghurt and cheese group $(60.2 \%)$, or the meat, poultry, fish, dry beans, eggs and nuts group (57.1\%). Almost half the participants did not know the daily recommended number of servings of fruit that should be consumed (44.7\%), or that peanut butter is high in fat (49.7\%); but most knew which foods have a high fibre content $(92.6 \%)$; that fried chicken has a high fat content $(97.5 \%)$, and that carrot is the best source of beta carotene $(96.3 \%)$.
TABLE 1: Socio-demographic status of nursing students $(N=161)$.

\begin{tabular}{|c|c|c|}
\hline Group & $\%$ & $\%$ \\
\hline \multicolumn{3}{|l|}{ Gender } \\
\hline Males & 51 & 31.7 \\
\hline Females & 110 & 68.3 \\
\hline \multicolumn{3}{|l|}{ Ages } \\
\hline Lower Quartile (25th) & 22.3 & - \\
\hline Median & 24.9 & - \\
\hline Upper Quartile (75th) & 28 & - \\
\hline \multicolumn{3}{|l|}{ Ethnicity } \\
\hline Black & 155 & 96.3 \\
\hline White & 2 & 1.2 \\
\hline Coloured & 4 & 2.5 \\
\hline \multicolumn{3}{|l|}{ Academic level of study } \\
\hline First year & 44 & 27.3 \\
\hline Second year & 42 & 26.1 \\
\hline Third year & 32 & 19.9 \\
\hline Fourth year & 43 & 26.7 \\
\hline \multicolumn{3}{|l|}{ Marital Status } \\
\hline Married & 20 & 12.4 \\
\hline Single & 141 & 87.6 \\
\hline \multicolumn{3}{|c|}{ Current place of Residence } \\
\hline University hostels & 109 & 67.7 \\
\hline Private rental & 28 & 17.4 \\
\hline At home & 23 & 14.3 \\
\hline Other & 1 & 0.6 \\
\hline \multicolumn{3}{|c|}{ Permanent place of residence } \\
\hline Urban Town & 33 & 20.5 \\
\hline Township & 60 & 37.3 \\
\hline Rural areas & 68 & 42.2 \\
\hline
\end{tabular}

$n$, Given as number of nursing students.

TABLE 2: Body weight status and fat distribution of nursing students $(N=161)$.

\begin{tabular}{|c|c|c|}
\hline Categories $\left(\mathrm{BMI} \mathrm{kg} / \mathrm{m}^{2}\right) \dagger$ & $n$ & $\%$ \\
\hline \multicolumn{3}{|l|}{ Male and female combined $(n=161)$} \\
\hline Underweight (BMI < 18.5 kg/m²) & 7 & 4.4 \\
\hline Normal weight (BMI $18.5-24.9 \mathrm{~kg} / \mathrm{m}^{2}$ ) & 74 & 45.9 \\
\hline Overweight (25-29.9kg/m²) & 51 & 31.7 \\
\hline Obese $\left(\mathrm{BMI} \geq 30 \mathrm{~kg} / \mathrm{m}^{2}\right)$ & 29 & 15.0 \\
\hline \multicolumn{3}{|l|}{ Male $(n=51)$} \\
\hline Underweight (BMI < 18.5 kg/m²) & 5 & 9.8 \\
\hline Normal weight (BMI $18.5-24.9 \mathrm{~kg} / \mathrm{m}^{2}$ ) & 30 & 58.8 \\
\hline Overweight $\left(25-29.9 \mathrm{~kg} / \mathrm{m}^{2}\right)$ & 11 & 21.6 \\
\hline Obese $\left(\mathrm{BMI} \geq 30 \mathrm{~kg} / \mathrm{m}^{2}\right)$ & 5 & 9.8 \\
\hline \multicolumn{3}{|l|}{ Female $(n=110)$} \\
\hline Underweight (BMI < 18.5 kg/m²) & 2 & 1.8 \\
\hline Normal weight (BMI $18.5-24.9 \mathrm{~kg} / \mathrm{m}^{2}$ ) & 44 & 40.0 \\
\hline Overweight $\left(25-29.9 \mathrm{~kg} / \mathrm{m}^{2}\right)$ & 40 & 36.4 \\
\hline Obese $\left(\mathrm{BMI} \geq 30 \mathrm{~kg} / \mathrm{m}^{2}\right)$ & 24 & 21.8 \\
\hline \multicolumn{3}{|l|}{ Waist Circumference (WC) Categories $(n=161)$} \\
\hline $\begin{array}{l}\text { Ideal category } \\
(<94 \mathrm{~cm} \text { male } \&<80 \mathrm{~cm} \text { female })\end{array}$ & 56 & 34.8 \\
\hline $\begin{array}{l}\text { Increased risk for chronic diseases of lifestyle category: } \\
\text { (94.0-101.9 cm male \& } 80.0-87.9 \mathrm{~cm} \text { female) }\end{array}$ & 43 & 26.7 \\
\hline $\begin{array}{l}\text { Substantially increased chronic diseases of lifestyle category } \$ \\
\geq 02 \mathrm{~cm} \text { male } \& \geq 88 \mathrm{~cm} \text { female }\end{array}$ & 62 & 38.5 \\
\hline $\begin{array}{l}\text { At risk for insulin resistance and the metabolic syndrome } \S \\
\geq 94 \mathrm{~cm} \text { male } \& \geq 80 \mathrm{~cm} \text { female }\end{array}$ & 105 & 65.2 \\
\hline \multicolumn{3}{|l|}{ Waist Hip Ratio (WHR) Categories $(n=161)$} \\
\hline $\begin{array}{l}\text { Ideal category } \\
<0.9 \text { males } \&<0.8 \text { female }\end{array}$ & 101 & 62.7 \\
\hline $\begin{array}{l}\text { Increased risk for chronic diseases of lifestyle category } \dagger \dagger \\
\geq 0.9 \text { for male } \& \geq 0.8 \text { for female }\end{array}$ & 60 & 37.3 \\
\hline
\end{tabular}
$\geq 0.9$ for male $\& \geq 0.8$ for female

$\dagger$, WHO BMI classification - Southern African Society for the Study of Obesity. Guidelines for the Prevention and Management of Overweight and Obesity in South Africa [homepage on the internet]. 2003 [cited 2011 Apr. 28]. Available
ClientFiles/Guidelines/SASSO\%20Guidelines.pdf

ClientFiles/Guidelines/SASSO\%20Guidelines.pdf $\$$, As defined by: Southern African Society for the Study of Obesity. Guidelines for the the internet]. 2003 [cited 2011 Apr. 28]. Available from: http://www.hypertension.org.za/ ClientFiles/Guidelines/SASSO\%20Guidelines.pdf

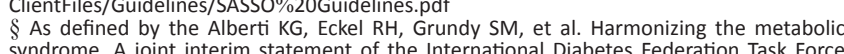
syndrome. A joint interim statement otional Heart, Lung, and Blood Institute; Americe on Epidemiology and Prevention, National Heart, Lung, and Blood Institute; American Heart Association; World Heart Federation; International; Atherosclerosis Society; an International Association for the Study of Obesity. Circulation. 2009;120:1640-1645. $n$, Given as number of nursing students. 
TABLE 3: Usual daily food intake of nursing students $(N=161)$.

\begin{tabular}{|c|c|c|c|}
\hline Food groups & Recommendations $\dagger$ & $n$ & $\%$ \\
\hline \multicolumn{4}{|c|}{ Breads, Cereal, Rice and Pasta } \\
\hline Below recommendations & $<6$ servings per day & 6 & 3.7 \\
\hline Within recommendations & $6-11$ servings per day & 134 & 83.2 \\
\hline High intakes & $>11$ servings per day & 21 & 13.1 \\
\hline \multicolumn{4}{|l|}{ Vegetables } \\
\hline Below recommendations & $<3$ servings per day & 157 & 97.5 \\
\hline Within recommendations & $3-5$ servings per day & 4 & 2.5 \\
\hline \multicolumn{4}{|l|}{ Fruits } \\
\hline Below recommendations & $<2$ servings per day & 68 & 42.2 \\
\hline Within recommendations & $2-4$ servings per day & 78 & 48.5 \\
\hline High intakes & $>4$ servings per day & 15 & 9.3 \\
\hline \multicolumn{4}{|l|}{ Milk and milk products } \\
\hline Below recommendations & $<2$ servings per day & 149 & 92.6 \\
\hline Within recommendations & $2-3$ servings per day & 12 & 7.5 \\
\hline \multicolumn{4}{|l|}{ Meat and meat alternatives } \\
\hline Below recommendations & $<2$ servings per day & 5 & 3.1 \\
\hline Within recommendations & $2-3$ servings per day & 26 & 16.2 \\
\hline High intakes & $>3$ servings per day & 130 & 80.8 \\
\hline \multicolumn{4}{|l|}{ Fats and oils } \\
\hline- & $\leq 4$ servings $(20 \mathrm{~g}) \neq$ per day & 80 & 49.7 \\
\hline- & $>4$ servings $(20 \mathrm{~g})$ per day & 81 & 50.3 \\
\hline \multicolumn{4}{|l|}{ Sweets and sugar } \\
\hline- & $\leq 4$ servings ( $40 \mathrm{~g}$ ) per day & 35 & 21.7 \\
\hline- & $>4$ servings ( $40 \mathrm{~g}$ ) per day & 126 & 78.3 \\
\hline \multicolumn{4}{|l|}{ Alcohol } \\
\hline Recommended allowance & $\leq 2$ units per day $\S$ & 159 & 98.8 \\
\hline Above recommendation & $>2$ units per day & 2 & 1.2 \\
\hline
\end{tabular}

$\dagger$, Evaluated according to the recommendations of the American Department of Agriculture's Food Guide Pyramid 1992 (Shaw A, Fulton L, Davis C, Hogbin M. Using the Food Guide Pyramid: A Resource for nutrition educators. U.S. Department of Agriculture Food, Nutrition, and Consumer Services Center For Nutrition Policy and Promotion. Accessed: 10 May 2011 Available form: http://www.nal.usda.gov/fnic/Fpyr/guide.pdf).

Available form: $h \mathrm{ttp}: / /$ www.nal.usda.gov/fnic/Fpyr/guide.pdf). $\$$, Based on the recommendation of the Dietary Guidelines for Americans 2010, that peopl oils (U.S. Departmenter. Dietary Guidelines for Americans 2010:79, Available at: www.dietaryguidelines.gov).

$\S$, National Institutes of Health, National Heart, Lung, and Blood Institute National High Blood Pressure Education Program: The Seventh Report of the Joint National Committee on Prevention, Detection, Evaluation, and Treatment of High Blood Pressure, NIH Publication No.04-5230, 2004.

$n$, Given as number of nursing students.

Almost two-thirds of the participants (65.4\%) had an overall score of more than $50 \%$ on the nutritional knowledge questionnaire and were classified as knowledgeable, whilst $34.6 \%$ of the participants had an overall score of less than $50 \%$ and were classified as not knowledgeable.

Most participants listed the media (47.8\%) and school or institution of teaching (35.4\%) as their sources of nutritional information. Parents (13.7\%) and friends (22.9\%) did not rank high as sources of information.

\section{Association between eating practices and body weight}

Median energy intakes were significantly higher for men (6 $333 \mathrm{~kJ})$ than for woman ( $5543 \mathrm{~kJ})(95 \%$ CI for median difference [236.7; 970.0]). No statistical differences were found between BMI or waist circumference categories with regard to gender, place of residence, number of meals per day, breakfast skipping, or median energy or macronutrient intakes. (Note however, that there were only seven participants in the underweight category).Significantly more underweight than overweight or obese participants, consumed fewer than six servings from the starch group daily [ $95 \%$ CI: $0.1 \%$; $50.1 \%$ ]. Significantly fewer underweight participants also consumed chips (crisps) on a daily basis than both normal weight [95\% CI: $-61.5 \% ;-1.7 \%$, and overweight or obese participants [95\% CI: $-66.0 \% ;-6.8 \%$ ]. Significantly fewer underweight participants also $(57 \%)$ consumed sweets or chocolates on a daily basis than overweight or obese participants (90\%) [95\% CI: $-65.3 \% ;-4.5 \%$ ] (Table 6).

Significantly more overweight or obese $(25 \%)$, than normal weight (12.2\%), participants consumed full cream milk on a daily basis [95\% CI: $-24.7 \% ;-0.4 \%$ ]. On the other hand, more underweight participants (57.1\%) than both overweight or obese participants (15\%) [95\% CI: 8.7\%; 69.9\%], and normal weight participants (16.2\%) [95\% CI: 7.3\%; 68.8\%] consumed low fat or skim milk on a daily basis.

\section{Association between nutritional knowledge and body weight}

Significantly more underweight participants (85.7\%) than both normal weight (35.1\%) [95\% CI: 11.8\%; 65.9\%) and overweight or obese participants (40\%) [95\% CI: 7.1\%; 61.1\%] knew how many dairy servings should be eaten daily. More normal weight participants (20.3\%) than overweight or obese participants $(8.8 \%)$ [95\% CI: $0.3 \% ; 22.9 \%$ ] knew the daily recommended servings for bread, cereal, rice and pasta; whilst more [95\% CI: 0.7; 22.5\%] normal weight (18.9\%) than overweight $(7.5 \%)$ participants knew that carrots are high in fibre. Significantly more underweight (28.6\%) than overweight or obese participants (3.8\%) [95\% CI: 3.4\%; 60.4\%] thought that hamburgers are high in fibre. Significantly more underweight $(14.3 \%)$ than overweight or obese participants (0\%) [95\% CI: $1.7 \%$; 51.3\%] knew that oranges are high in vitamin C. More overweight or obese (95\%) participants [95\% CI: $-59.2 \%$; $-2.0 \%$ ] than underweight $(71.4 \%)$ participants knew that carrots are a good source of $\beta$-carotene.

Participants with adequate nutritional knowledge (who scored $\geq 50 \%$ on the knowledge questionnaire) did not eat significantly different from those with inadequate nutritional knowledge (who scored $<50$ ) regarding any of the food items listed (Table 4).

\section{Discussion}

In this study the prevalence of overweight or obesity amongst these nursing students was higher than the national statistics reported from the SADHS $2003^{3}$ for the general South African population. However, $96.3 \%$ of the participants in the current study were Black persons and their overweight or obesity prevalence and trends very closely reflect national statistics, as well as trends, for the South African Black population $>15 y$ rs (27.2\% for men; $56.2 \%$ for woman), reported by the SADHS 2003; ${ }^{3}$ as well as statistics $(53.3 \%$ overweight or obese) reported for Black woman 25-34yrs in Mangaung, Free State. ${ }^{29}$ Only seven participants were underweight and, 
TABLE 4: Frequency of food consumption of nursing students $(N=161)$.

\begin{tabular}{|c|c|c|c|c|c|c|}
\hline \multirow[t]{2}{*}{ Food } & \multicolumn{2}{|c|}{ Do not eat } & \multicolumn{2}{|c|}{ Eat monthly } & \multicolumn{2}{|c|}{ Eat daily } \\
\hline & $n$ & $\%$ & $n$ & $\%$ & $n$ & $\%$ \\
\hline Sweets and/or chocolates & 7 & 4.4 & 124 & 77.0 & 30 & 18.6 \\
\hline Chips (crisps) & 17 & 10.6 & 134 & 83.2 & 10 & 6.2 \\
\hline Cakes and/or biscuits & 19 & 11.8 & 138 & 85.7 & 4 & 2.5 \\
\hline Cooldrinks & 13 & 8.1 & 116 & 72.1 & 32 & 19.8 \\
\hline Cremora & 78 & 48.4 & 60 & 37.3 & 23 & 14.3 \\
\hline Coffee & 43 & 26.7 & 84 & 52.2 & 34 & 21.1 \\
\hline Tea & 63 & 39.1 & 70 & 43.5 & 28 & 17.4 \\
\hline Sugar & 9 & 5.6 & 57 & 35.4 & 95 & 59.0 \\
\hline Full cream milk & 31 & 19.3 & 110 & 68.3 & 20 & 12.4 \\
\hline Low fat/skim milk & 124 & 77.0 & 32 & 19.9 & 5 & 3.1 \\
\hline Eggs & 9 & 5.6 & 132 & 82.0 & 20 & 12.4 \\
\hline Peanut Butter & 69 & 42.9 & 91 & 56.5 & 1 & 0.6 \\
\hline $\begin{array}{l}\text { Soya minced/legumes (baked beans, } \\
\text { dried beans, peas and lentils) }\end{array}$ & 74 & 46.0 & 86 & 53.4 & 1 & 0.6 \\
\hline Red meat & 18 & 11.2 & 142 & 88.2 & 1 & 0.6 \\
\hline Fish & 33 & 20.5 & 125 & 77.6 & 3 & 1.9 \\
\hline Bread & 0 & 0.0 & 71 & 44.1 & 90 & 55.9 \\
\hline Cooked porridge & 55 & 34.2 & 106 & 66.8 & 0 & 0.0 \\
\hline Cereal (Morevit/Pronutro) & 42 & 26.1 & 113 & 70.2 & 6 & 3.7 \\
\hline Samp and/or mielie rice & 32 & 19.9 & 123 & 76.4 & 6 & 3.7 \\
\hline Margarine and/or oil or fat & 1 & 0.6 & 50 & 31.1 & 110 & 68.3 \\
\hline Fruit juice & 16 & 9.9 & 111 & 68.9 & 34 & 21.2 \\
\hline Fruit & 0 & 0.0 & 123 & 76.4 & 38 & 23.6 \\
\hline Vegetables & 4 & 2.5 & 137 & 85.4 & 20 & 12.4 \\
\hline Salt and/or stork or Royco & 0 & 0.0 & 22 & 13.7 & 139 & 86.3 \\
\hline Alcohol & 119 & 73.9 & 41 & 25.5 & 1 & 0.6 \\
\hline
\end{tabular}

$n$, Given as number of nursing students.

TABLE 5: Responses to nutritional knowledge questions $(N=161)$.

\begin{tabular}{|c|c|c|c|c|}
\hline \multirow[t]{2}{*}{ Nutritional knowledge tested $\dagger$} & \multicolumn{2}{|c|}{ Answered incorrectly } & \multicolumn{2}{|c|}{ Answered correctly } \\
\hline & $n$ & $\%$ & $n$ & $\%$ \\
\hline Which food group should be eaten the most & 110 & 68.3 & 51 & 31.7 \\
\hline Which food group should be eaten the least & 40 & 24.8 & 121 & 75.2 \\
\hline Daily recommended number of servings for fruits & 72 & 44.7 & 89 & 55.3 \\
\hline Daily recommended number of servings of milk and/or yoghurt and cheese & 97 & 60.2 & 64 & 39.8 \\
\hline Daily recommended number of servings of bread, cereal, rice and pasta & 138 & 85.7 & 23 & 14.3 \\
\hline Daily recommended number of servings of vegetables & 88 & 54.7 & 73 & 45.3 \\
\hline Daily recommended number of servings of meat, poultry, fish, dry beans, eggs and nuts & 92 & 57.1 & 69 & 42.9 \\
\hline Which foods are high in fibre & 12 & 7.5 & 149 & 92.6 \\
\hline Fried chicken as food with high fat content & 4 & 2.5 & 157 & 97.5 \\
\hline Peanut butter as food with high fat content & 80 & 49.7 & 81 & 50.3 \\
\hline Foods which are best sources of $\beta$ carotene & 6 & 3.7 & 155 & 96.3 \\
\hline
\end{tabular}

Foods which are best sources of $\beta$ caroten

$\dagger$, Questions and answers based on:

- Shaw A, Fulton L, Davis C, Hogbin M. Using the Food Guide Pyramid: A Resource for nutrition educators. U.S. Department of Agriculture Food, Nutrition, and Consumer Services Center For Nutrition Policy and Promotion [home page on the internet]. No date.[ cited: 2011 May 10. Available form: http://www.nal.usda.gov/fnic/Fpyr/guide.pdf

- The South African Food Based Dietary Guidelines [home page on the internet]. 2011cited 2011 May 10]. Available from: http://www.sahealthinfo.org/nutrition/foodbasedsept 2001.pdf

- U.S. Department of Agriculture and U.S. Department of Health and Human Services. Dietary Guidelines for Americans, 2010. 7th Edition, Washington, DC: U.S. Government Printing Office, 2010:79.

$n$, Given as number of nursing students.

also in keeping with the findings of the SADHS ${ }^{3}$ and other South African studies, ${ }^{30}$ five of these were male.

In contrast, the percentages of overweight or obesity reported in this study were higher than those reported for Black participants at other South African universities in the past. For example, Morar et al. ${ }^{31}$ reported a prevalence of overweight or obesity of $24.3 \%$ for Black medical students at the University of Natal. Cilliers et al. ${ }^{32}$ reported a prevalence of overweight or obesity of $24.7 \%$ in Black first-year students at the University of Stellenbosch; whilst the prevalence of overweight or obesity amongst first-year female students was $25 \%$ at the University of Limpopo (Turfloop Campus) in $2000 .^{33}$

Overweight or obesity figures of the Black nursing students in the current study are however similar to statistics reported for students at universities or colleges in North America ${ }^{34,35}$ (where similar statistics have also been reported amongst graduate health care professionals ${ }^{20}$ ), but was higher than those reported for some other developing countries in the Middle East ${ }^{36}$ and Asia. ${ }^{37}$ This might indicate that the problem 
TABLE 6: Association between Body Mass Index and frequency of food consumption $(N=161)$.

\begin{tabular}{|c|c|c|c|c|c|c|}
\hline \multirow[t]{2}{*}{ Foods } & \multicolumn{2}{|c|}{ Underweight $\dagger$} & \multicolumn{2}{|c|}{ Normal weight: } & \multicolumn{2}{|c|}{ Overweight/obese $\S$} \\
\hline & $\%$ & $n$ & $\%$ & $n$ & $\%$ & $n$ \\
\hline \multicolumn{7}{|c|}{ Sweets and chocolates } \\
\hline Never eats & 0 & 0 & 0 & 0 & 0 & - \\
\hline Eats monthly & 42.9 & 3 & 14.9 & 11 & 10 & 8 \\
\hline Eats daily & 57.1 & 4 & 85.1 & 63 & 90 & 72 \\
\hline \multicolumn{7}{|l|}{ Chips (crisps) } \\
\hline Never eats & 0 & 0 & 0 & 0 & 1.3 & 1 \\
\hline Eats monthly & 71.4 & 5 & 32.4 & 24 & 26.3 & 21 \\
\hline Eats daily & 28.6 & 2 & 67.6 & 50 & 72.5 & 58 \\
\hline \multicolumn{7}{|c|}{ Cakes and/or biscuits } \\
\hline Never eats & 0 & 0 & 5.4 & 4 & 6.3 & 5 \\
\hline Eats monthly & 14.3 & 1 & 32.4 & 24 & 40.0 & 32 \\
\hline Eats daily & 85.7 & 6 & 62.2 & 46 & 53.8 & 43 \\
\hline \multicolumn{7}{|l|}{ Cool drinks } \\
\hline Eats monthly & 42.9 & 3 & 40.5 & 30 & 47.5 & 38 \\
\hline Eats daily & 57.1 & 4 & 59.5 & 44 & 52.5 & 42 \\
\hline \multicolumn{7}{|c|}{ Full cream milk } \\
\hline Never eats & 0 & 0 & 5.4 & 4 & 3.8 & 3 \\
\hline Eats monthly & 85.7 & 6 & 82.4 & 61 & 71.3 & 57 \\
\hline Eats daily & 14.3 & 1 & 12.2 & 9 & 25.0 & 20 \\
\hline \multicolumn{7}{|c|}{ Low fat and/or skim milk } \\
\hline Never eats & 14.3 & 1 & 37.8 & 28 & 42.5 & 34 \\
\hline Eats monthly & 28.6 & 2 & 45.9 & 34 & 42.5 & 34 \\
\hline Eats daily & 57.1 & 4 & 16.2 & 12 & 15.0 & 12 \\
\hline
\end{tabular}

$n$, Given as number of nursing students.

$\dagger, n=7$.

$\because, n=74$

of overweight or obesity amongst Black students in South Africa is escalating, possibly due to rapid urbanisation and nutrition and lifestyle transitions to Western patterns.

In the current study, two-thirds of the nursing students $(65.2 \%)$ had waist circumferences that put them at risk for insulin resistance and the metabolic syndrome according to the guidelines of the New Joint Classification for the Diagnosis of Metabolic Syndrome. ${ }^{5}$ Moreover, 38.5\% of the participants had a waist circumference indicating substantial risk for NCD ( $\geq 102 \mathrm{~cm}$ for males; $\geq 88 \mathrm{~cm}$ for females). ${ }^{4}$ The high levels of truncal obesity in these participants was also confirmed by $37.3 \%$ of participants who had waist-hip-ratios indicative of increased health risk ( $\geq 0.9$ for males; $\geq 0.8$ for females). These figures are similar to the $42 \%$ reported by the SADHS $1998^{38}$ (using waist-hip-ratio cut-off points of $\geq 0.9$ for males; $\geq 0.8$ for females); and higher than what was reported by the SADHS 2003 (but which used higher waisthip-ratio cut-off points of $\geq 1.0$ for males; $\geq 0.85$ for females) for Black men (5.1\%) and women $(31.7 \%){ }^{3}$

Quantification of the 24-hour recalls revealed quite low energy intakes, which in the light of the levels of overweight or obesity in this group, raised suspicions that the 'flat-slope syndrome' - which refers to the phenomenon that participants with high actual consumptions often underestimate the amount of food and drink they recall ${ }^{21}-$ may have occurred; and/or may reflect low activity levels (which were not assessed in this study). Analysis of the 24hour recalls of these predominantly Black nursing students, according to the food groups on the USDA-FGP, revealed low intakes of vegetables, fruit and dairy, which is characteristic of the nutritional transition reported by numerous studies amongst urbanised Black South African communities.,12 These signs of nutritional transition were also evident from the food frequency questionnaires obtained from this group: most participants consumed margarine, oil or fat and sugar on a daily basis, whilst few consumed vegetables, fruit, fruit juice and milk on a daily basis. Interestingly, most of the participants were from rural areas $(42.2 \%)$ or townships $(37.3 \%)$ and resided at the university hostels. The fact that they were living on campus may have contributed to fasttrack the nutrition transition.

Vegetables and fruits are sources of vitamins, minerals, fibre and numerous phytochemicals which offer protection against NCD, including cardiovascular disease, type 2 diabetes and cancer, by various mechanisms which include acting as anti-oxidants that scavenge free radicals, enhancing the performance of the liver detoxification enzyme systems, and suppressing cancer cell initiation and/or proliferation. ${ }^{39}$ The finding that only $2.5 \%$ of these participants ate at least three vegetables daily, that almost half the participants (42.2\%) did not eat at least two portions of fruit or fruit juice per day, and that the overall frequency of the intake of vegetables and fruits was very low, therefore poses a serious health risk. The nutritional knowledge questionnaire revealed that most of the participants also did not know the daily recommended number of servings that should be consumed from the vegetable and fruit groups. Nutritional knowledge 
is believed to play an important role in promoting healthier eating practices, and increased knowledge of dietary guidelines has been positively linked to more healthy eating practices amongst college students. ${ }^{40}$

Osteoporosis is another chronic disease risk posed by the fact that $92.6 \%$ of the participants consumed less than two servings of milk or dairy products per day, whilst only $15.8 \%$ indicated that they consume milk daily. Once again, the nutritional knowledge questionnaire revealed that most participants $(60.2 \%)$ did not know how much milk or dairy products they ought to consume. The prevalence of osteoporosis is on the rise in SA - even amongst the Black population who is less prone to low bone density than Whites and Asians. ${ }^{41}$ The majority of the participants in the current study were in their twenties and had not reached peak bone density (at around 30 years) yet. Reaching an optimum peak bone density is considered one of the best ways to counteract the early onset of osteoporosis, and consuming adequate amounts of milk or dairy products is considered the most practical, effective and relatively inexpensive (when compared to the cost of supplements) way to acquire adequate calcium to optimise bone density. ${ }^{42}$ As the majority of the participants were Black South Africans, a high level of lactose intolerance may be expected amongst them. ${ }^{43}$ However, amongst South African Black persons, the use of fermented buttermilk, such as amazi which contains low levels of lactose, is part of the traditional eating habits. ${ }^{43}$ When students in a recent study (2010 - as yet unpublished results) amongst students on the University of the Free State (where 55\% of students were Black students in 2010), were however asked to rank their preferences for foods that they would buy if available and affordable on campus, amazi and other traditional foods were ranked surprisingly low. This may confirm that the food preferences of Black South African students at University are westernised. A recent study confirmed a decrease in calcium intake with urbanisation amongst Black woman in the North West Province of South Africa. ${ }^{41}$ Weight-bearing exercise and other osteoprotective factors were not assessed in the current study.

Both the 24-hour recalls and the food frequency questionnaires pointed out high intakes of fat and sugar or sweets, although most participants were knowledgeable about the fact that these foods should be consumed sparingly. A practical way of cutting back on total and saturated fat intake is by substituting full cream milk with low fat or skim milk, however $76.5 \%$ of the participants reported that they do not use low fat or skim milk. Some significant associations could also be shown between higher fat and sugar intake in the overweight or obese participants compared to normal and/or underweight participants.

Self-reported alcohol intakes (Table 3) were within prudent guidelines. ${ }^{27}$ Most participants (73\%) reported not using any alcohol and less than $1 \%$ reported daily consumption of alcohol. This is in contrast with reports of high alcohol consumption amongst university or college students in South Africa (2010 - yet unpublished study amongst students at the
University of the Free State) and abroad ${ }^{44}$ yet underreporting is a possibility.

\section{Recommendations}

Studies show that doctors and nurses are more likely to discuss weight, diet and lifestyle issues with their patients and use strategies to prevent obesity in patients if they themselves have a normal BMI. ${ }^{20}$ Literature also identifies lack of nutritional knowledge and confidence on the part of the health care provider as significant barriers which prevent health care workers from offering dietary support. ${ }^{18,19}$ The fact that almost half of the nursing students in this study were overweight or obese and many lacked basic nutritional knowledge, may therefore impact negatively on their efficacy as future health care professionals. With rates of obesity and associated risks for NCD soaring in South Africa, universities or colleges are today faced with the significant challenge of how to meet these barriers and equip health care providers to support healthy choices and address risk factors in patients whilst primary prevention is still possible. The learning content of the training that nurses and other health professionals receive regarding nutrition and lifestyle should be critically reappraised towards this end.

However, knowledge of good eating habits and a healthy lifestyle is not necessarily enough to motivate health care professionals to practice what they (ought to) preach. Creating an environment that is supportive of healthy eating habits and an active lifestyle, as well as requiring health care students to show competence at applying these principles in their own lives, may go a long way towards achieving this aim. Future research should be directed at finding the most appropriate ways in which to create such structures for different student populations in different cultural settings. This would at least empower the future health care professionals to take charge of their own health, which may increase their efficacy in dealing with nutrition, health and weight issues in their patients.

\section{Conclusions}

These South African nursing students, mainly from rural areas and townships, living in hostels at the University of Fort Hare, Eastern Cape, had a high prevalence of overweight and obesity, poor eating habits and inadequate knowledge on key nutritional issues, which puts them at risk for chronic diseases of lifestyle. As future health care professionals, this may impact negatively on their efficacy as health ambassadors to the public.

\section{Acknowledgements}

The authors thank the nursing students of the University of Fort Hare, for their participation in this study, as well as Professor C.M. Walsh of the University of the Free State for her meaningful contributions. Partial funding for this study came from the Govan Mbeki Research and Development Centre (RDC) and the University of Fort Hare. 


\section{Competing interest}

The authors declare that they have no financial or personal relationship(s) which may have inappropriately influenced them in writing this paper.

\section{Author contributions}

A.P.O. (University of the Free State) planned the project, and collected and interpreted the data to fulfil the requirements of the degree Master's in Nutrition at the University of the Free State; A.D. (University of the Free State) was the study leader; V.L.v.d.B. (University of the Free State) made substantial interpretational contributions and wrote the article; M.N. (University of the Free State) advised on the study design and sampling procedures and also performed the statistical analysis.

\section{References}

1. Steyn NP, Bradshaw D, Norman R, Joubert J, Schneider M, Steyn K. Dietary changes and the health transition in South Africa: implications for health policy. 2006. [homepage on the Internet] No date [cited 2011 April 28] Available from April 2011. Available from: http://www.sahealthinfo.org/lifestyle/dietaccess.htm.

2. Holmes MD, Dalal S, Volminkv J, et al. Non-Communicable Diseases in Sub-Saharan Africa: The Case for Cohort Studies. PLoS Medicine. 2010; 7(5):e1000244. http:// dx.doi.org/10.1371/journal.pmed.1000244, PMid:20485489, PMCid:2867939

3. Department of Health, Republic of South Africa 2003 Health and Demographic Survey (full report p. 276-277). 2007. [homepage on the Internet] No date [cited 2011 April 28] Available from http://www.mrc.ac.za/bod/sadhs.htm.

4. Alberti KG, Eckel RH, Grundy SM, et al. Harmonizing the metabolic syndrome. A joint interim statement of the International Diabetes Federation Task Force on joint interim statement of the International Diabetes Federation Task Force on Heart Association; World Heart Federation; International; Atherosclerosis Society; and International Association for the Study of Obesity. Circulation. Society; and International Association for the Study of Obesity. Circulation. 2009; $120: 1640-16$

5. Southern African Society for the Study of Obesity. Guidelines for the Prevention and Management of Overweight and Obesity in South Africa. 2003. [homepage on the Internet] No date [cited 2011 April 28] Available from http://www. hypertension.org.za/ClientFiles/Guidelines/SASSO\%20Guidelines.pdf.

6. Bradshaw D, Groenewald P, Laubscher R, et al. Initial Burden of Disease Estimates for South Africa, 2000. Cape Town: South African Medical Research Council. 2300.

7. Gee M, Mahan LK, Escott-Stump S. Weigh management. In: Mahan KL, EscottStump S, editors. Krause's food, nutrition and diet therapy. 12th ed. Philadelphia: Elsevier; 2008; p. 532-562.

8. Kirk SFL, Penney TL, McHugh TF. Characterising the obesogenic environment: the state of the evidence with directions for future research. Obes Rev. 2009;11:109 117. http://dx.doi.org/10.1111/j.1467-789X.2009.00611.x, PMid:19493302

9. Ledikwe JH, Blanck HM, Khan LK, et al. Dietary energy density is associated with energy intake and weight status in US adults. Am J Clin Nutr. 2006;83:1362-1368.

10. Lanou AJ, Barnard ND. Dairy and weight loss hypothesis: an evaluation of the clinical trials. Nutr Rev. 2008;66(5):272-279.

11. Berkey CS, Rockett HRH, Gillman MW, Field AE, Colditz GA. Longitudinal study of skipping breakfast and weight change in adolescents. Int J Obes. 2003;27:12581266. http://dx.doi.org/10.1111/j.1467-789X.2009.00611.x, PMid:19493302

12. Bourne LT, Lambert EV, Steyn K. Where does the black population of South Africa stand on the nutrition transition? Pub Health Nutr. 2002;5(1a):157-162. http:// dx.doi.org/10.1079/PHN2001288, PMid:12027279

13. Kruger HS, Venter CS, Vorster HH, Margetts BM. Physical inactivity is a major determinant of obesity in black women in the North West Province, South Africa: the THUSA study. Nutr. 2002;18(5):422-427. http://dx.doi.org/10.1016/S08999007(01)00751-1

14. Pignone MP, Ammerman A, Fernandez $L$, et al. Counseling to promote a healthy diet in adults: A summary of the evidence for the U.S. Preventive Services Task Force. Am J Prev Med. 2003;24(1):75-92. http://dx.doi.org/10.1016/S07493797(02)00580-9

15. Jackson AA. Human nutrition in medical practice: the training of doctors. Proc Nutr Soc. 2001;60(20):257-63. http://dx.doi.org/10.1079/PNS200081

16. van Binsbergen JJ, Delaney BC, van Weel C. Nutrition in primary care: scope and relevance of output from the Cochrane Collection. Am J Clin Nutr. 2003;77(4):1083S-1088S. PMid:12663322

17. van Weel C. Dietary advice in family medicine. Am J Clin Nutr. 2003;77(4):1008S-1010S. PMid:12663308

18. Kushner RF. Barriers to providing nutrition counselling by physicians: a survey of primary care practitioners. Prev Med. 1995;24(6):546-552. http://dx.doi. org/10.1006/pmed.1995.1087, PMid:8610076.
19. Ockene IS, Hebert JR, Ockene JK, Merriam PA, Hurley TG, Saperia GM. Effect of training and a structured office practice on physician-delivered nutrition counselling: WATCH. Am J Prev Med. 1996;12(4):252-258. PMid:8874688

20. Zhu DQ, Norman IJ, While AE. The relationship between doctors' and nurses' own weight status and their weight management practices: a systematic review. Obesity Reviews. Pre-publication view. 2011. [homepage on the Internet] No date [cited 2011 May 08] Available from http://onlinelibrary.wiley.com/doi/10.1111/ [cited 2011 May 08] Available fror

21. Lee RD, Nieman DC. Nutritional assessment. 4th ed. Boston: McGraw Hill; 2007 p.8, p.187-188.

22. Shaw A, Fulton L, Davis C, Hogbin M. Using the Food Guide Pyramid: A Resource for nutrition educators. U.S. Department of Agriculture Food, Nutrition, and Consumer Services Center For Nutrition Policy and Promotion [homepage on the Internet] No date [cited 2011 May 10] Available from http://www.nal.usda.gov/ fnic/Fpyr/guide.pdf

23. South African Food Based Dietary Guidelines [homepage on the Internet] No date [cited 2011 May 10] Available from http://www.sahealthinfo.org/nutrition/ foodbasedsept 2001.pdf

24. U.S. Department of Agriculture and U.S. Department of Health and Human Services. Dietary Guidelines for Americans, 2010. 7th ed. Washington, DC: U.S. Government Printing Office, 2010. p. 79.

25. Wheeler M, Franz MJ, Madelyn L, et al. Macronutrient and energy database for the 1995 Exchange Lists for meal planning: a rationale for clinical practice decisions. J Am Diet Assoc. 1996;96(11):1167-1171. http://dx.doi.org/10.1016/ S0002-8223(96)00299-4

26. Wolmarans P, Danster N, Dalton A, Rossouw K, Schönfeldt H, editors. Condensed Food Composition Tables for South Africa. Parow Valley, Cape Town, Medical Research Council; 2010.

27. Langenhoven ML, Conradie PJ, Wolmarans P, Faber M. MRC Food Quantities Manual. 2nd ed. Parow: South African Medical Research Council;1991.

28. National Institutes of Health. National Heart, Lung, and Blood Institute Nationa High Blood Pressure Education Program: The Seventh Report of the Joint Nationa Committee on Prevention, Detection, Evaluation, and Treatment of High Blood Pressure. NIH Publication. 2004;04-5230.

29. Hattingh Z, Walsh CM, Veldman FJ, Bester CJ. Oguntibeju OO. Anthropometric and biochemical profiles of black South African women. Afr J Biomed Res. 2008;11:161-172.

30. Puoane T, Steyn K, Bradshaw D, et al. Obesity in South Africa: the South African demographic and health survey. NAASO. 2002;10:1038-1048.

31. Morar N, Seedat YK, Naido DP. Ambulatory blood pressure and risk factors for coronary heart disease in black and Indian medical students. J Cardiovasc Risks. 1998;5(2):313-318. http://dx.doi.org/10.1097/00043798-19981000000005 , PMid:9920002

32. Cilliers J. Impact of a multidimensional weight-management programme on the weight status and associated factors of first year female students [unpublished MSc thesis]. Nutrition Science, University of Stellenbosch, South Africa; 2004.

33. Steyn NP, Senekal M, Brtis S, Nel J. Urban and rural differences in dietary intake, weight status and nutritional knowledge of black female students. Asia Pacific Clin Nutr. 2000; 9(1):53-59. http://dx.doi.org/10.1046/j.1440-6047.2000.00137.x

34. Huang TK, Jo Harris K, Lee RE, Nazir N, Born W, Kaur H. Assessing overweight, obesity, diet, and physical activity in college students. J Am College Health. 2003;52(2):8386. http://dx.doi.org/10.1080/07448480309595728, PMid:14765762

35. García-Alcala H, Cuevas-Ramos D, Genestier-Tamborero $\mathrm{Ch}$, et al. Significant increment in the prevalence of overweight and obesity documented between 1994 and 2008 in Mexican college students. Diabet Metab Syndr Obes. 2010;3:79-85.

36. Zafar S, Haque I, Butt AR, et al. Relationship of body mass index and waist to hip ratio measurements with hypertension in young adult medical students. Pakistan J Med Sc. 2007; 23:1-9.

37. Sakamaki R, Toyama K, Amamamoto R, Liu C-J, Shinfuku N. Nutrional knowledge, food habits and health attitude of Chinese university students: a cross sectional study. Centr Nut J. 2005;4(4):1-9.

38. Puoane T, Steyn K, Bradshaw D, et al. Obesity in South Africa: the South African demographic and health survey. NAASO. 2002; 10: 1038-1048.

39. Van Dokkum W, Frølich W, Saltmarsh M, Gee J. The health effects of bioactive plant components in food: results and opinions of the EU COST 926 action Nutr Bull. 2008;33: 133-139. http://dx.doi.org/10.1080/07448480309595728, PMid:14765762

40. Kolodinsky J, Harvey-Berino JR, Berlin L, Johnson RK, Reynolds TW. Knowledge of current dietary guidelines and food choice by college students: better eaters have higher knowledge of dietary guidance. J Am Diet Assoc. 2007;107(8):1409-1413. http://dx.doi.org/10.1016/j.jada.2007.05.016, PMid:17659910

41. Kruger MC, de Winter R, Becker PJ, Vorster HH. Changes in markers of bone turnover following urbanisation of black South African women. J Endocrinol, Metabol and Diabet of S Afr. 2004;9(1):9-14

42. Anderson JJB. Bone Health. In: Mahan KL, Escott-Stump S, editors. Krause's food, nutrition and diet therapy. 12th ed. Philadelphia: Elsevier, 2008; p. 532-62.

43. Segal I, Gagjee PP, Essop AR, Noormohamed AM. Lactase deficiency in the South African black population. Am J Clin Nutr. 1983;38(6):901-905. PMid:6650448.

44. Karam E, Kypri K, Marianac S. Alcohol use among college students: an international perspective. Curr Opin Psychiatry. 2007;20(3):213-221. PMid:17415072 